Czerewacz-Filipowicz K., Polityka migracyjna jako ptaszczyzna funkcjonalna integracji ekonomicznej w ramach Euroazjatyckiej Wspólnoty Gospodarczej, „Ekonomia i Prawo”, Polszakiewicz B., Boehlke J. (red.), Tom XII, nr 1/2013, ss. 57-68 DOI: http://dx.doi.org/10.12775/EiP.2013.005

\title{
POLITYKA MIGRACYJNA JAKO PŁASZCZYZNA FUNKCJONALNA INTEGRACJI EKONOMICZNEJ W RAMACH EUROAZJATYCKIEJ WSPÓLNOTY GOSPODARCZEJ
}

\section{STRESZCZENIE}

Celem niniejszego artykułu jest próba analizy efektów integracyjnych w ramach Euroazjatyckiej Wspólnoty Gospodarczej (ros. Евразийское экономическое сообщество, ЕврАзЭС, ang. EurAsEC) przez pryzmat jednego z obszarów funkcjonalnych, a mianowicie polityki migracyjnej, i potraktowanie jej, jako potencjalnego generatora efektów spill-over. Podpisanie i wejście w życie umowy o statusie prawnym pracowników -migrantów i członków ich rodzin oraz umowy w sprawie współpracy polegającej na przeciwdziałaniu nielegalnej migracji z państw trzecich, oznaczało przejście na nowy jakościowo poziom wzajemnych stosunków międzypaństwowych. Usunięcie granic w ramach Unii Celnej między Rosją, Kazachstanem i Białorusią oraz perspektywa dołączenia Kirgistanu i Tadżykistanu spowoduje przeniesie granic i kontroli celnej na zewnętrzne granice EAWG. Do skutecznej i efektywnej współpracy w tym zakresie należy nie tylko utworzyć pewne organy koordynujące, ale również potrzebna będzie skoordynowana praca parlamentów narodowych i władzy wykonawczej.

Słowa kluczowe: Euroazjatycka Wspólnota Gospodarcza, Federacja Rosyjska, migracje Klasyfikacja JEL: F15, F22

* Katarzyna Czerewacz-Filipowicz, Politechnika Białostocka, Wydział Zarządzania, Katedra Ekonomii i Nauk Społecznych, ul. Ojca Tarasiuka 2, 16-001 Kleosin, e-mail: kacz@pb.edu.pl. 


\title{
MIGRATION POLICY AS A FUNCTIONAL PLATFORM OF ECONOMIC INTEGRATION WITHIN THE EURASIAN ECONOMIC COMMUNITY
}

\author{
SUMMARY
}

The article aims to analyze the effects of integration in the Eurasian Economic Community (Rus. Евразийское экономическое сообщество, ЕврАзЭС) through the prism of one of the functional areas, namely the migration policy, and treating it as a potential generator of spill-over effects. Signing and entry into force of the agreement on the legal status of migrant workers and members of their families, and the agreement on cooperation in the prevention of illegal migration from the third countries, marked the transition to a qualitatively new level of interstate relations. The removal of the borders within the Customs Union among Russia, Kazakhstan and Belarus with the prospect of Kyrgyzstan and Tajikistan joining in, will cause the borders and customs control to be moved to the external borders of EurAsEC. For successful and effective cooperation in this regard, not only some coordinating bodies should be created, but also there will be a need for coordinated work of national parliaments and the executive authority.

Keywords: Eurasian Economic Community, Russian Federation, migration

JEL Classification: F15, F22

\section{WSTĘP}

Euroazjatycka Wspólnota Gospodarcza (EAWG) została utworzona 10 października 2000 r. przez Federację Rosyjską, Białoruś, Kazachstan, Kirgizję i Tadżykistan, w wyniku przekształcenia istniejącej od 1995 r. Unii Celnej. Organizacja „wchłonęła” lub może raczej zakwestionowała potrzebę dalszego funkcjonowania Centralnoazjatyckiej Organizacji Współpracy (utworzonej w 2002 r. przez Kazachstan, Kirgizję, Tadżykistan i Uzbekistan). Formalnie istnieje od maja 2001 r., kiedy to wszystkie państwa założycielskie ratyfikowały umowę ${ }^{1}$. W latach 2005-2008 również Uzbekistan był członkiem EAWG. W gronie obserwatorów znalazły się zaś Ukraina i Mołdawia (od maja 2002) oraz Armenia (od stycznia 2003).

Za priorytety w procesie tworzenia EAWG uznano m.in.: wypracowanie wspólnych zasad wolnego handlu towarami i usługami na obszarze wspólnoty,

\footnotetext{
${ }^{1}$ EurAsEC Today, Eurasian Economic Community Integration Committee Secretariat, Moscow 2011, s. 2.
} 
powołanie unii celnej, umożliwienie swobody przepływu kapitału i integrację rynków finansowych, ujednolicenie zasad prowadzenia działalności gospodarczej, umożliwienie swobody przepływu osób, unifikację systemów podatkowych, ujednolicenie polityki walutowej, współpracę w dziedzinie energetyki (stworzenie wspólnego rynku energii) i transportu, a także stworzenie wspólnych koncepcji rozwoju społeczno-gospodarczego ${ }^{2}$.

Celem niniejszego artykułu jest przestawienie polityki migracyjnej jako płaszczyzny funkcjonalnej, która generuje określone efekty wpływając na ekonomiczną integrację w ramach EAWG. Przepływy ludności między państwami członkowskimi EAWG wynikają z różnych uwarunkowań i potrzeb poszczególnych krajów, niemniej w każdym z nich stanowią ważny czynnik wpływający na rozwój ekonomiczny dlatego istotne jest zrozumienie konsekwencji jakie powodują również dla całej Euroazjatyckiej Wspólnoty Gospodarczej.

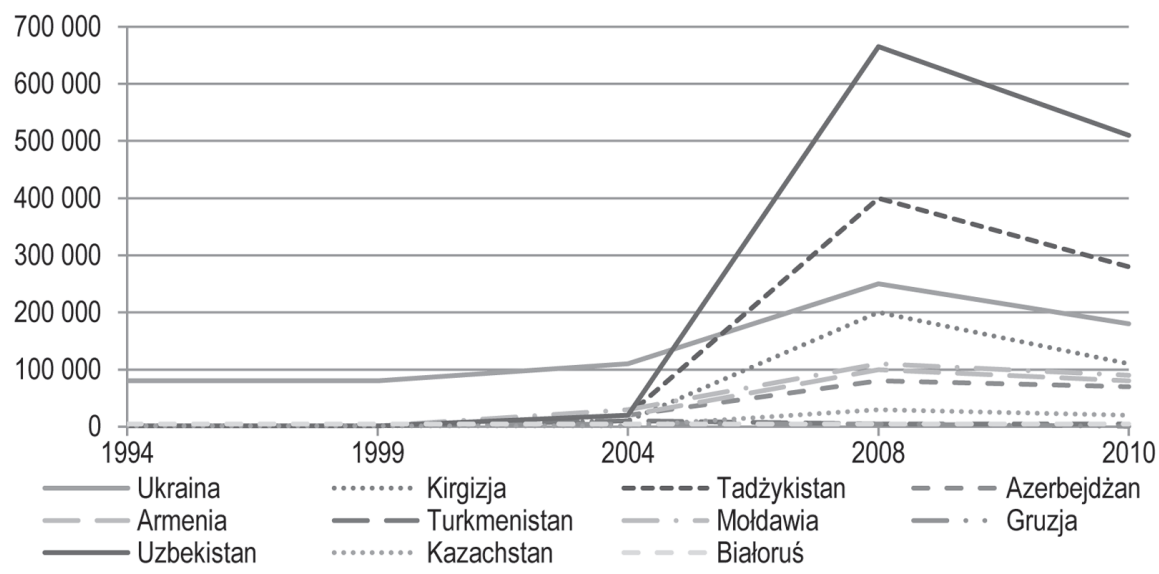

Wykres 1. Liczba obywateli krajów WNP aktywnych zawodowo w Rosji w tysiącach (w latach 1994, 1999, 2004, 2008, 2010)

Źródło: В. А. Ионцев, И. В. Ивахнюк, А. Г. Магомедова, И. А. Алешковский, Ю. А. Прохорова, К. Д. Шевченко, Е. В. Глод, Единый рынок труда в ЕЭП: экономический эффект соглашений в области трудовой миграчии, „Евразийская Экономическая Интеграция. Научно-аналитический Журнал”, 2012, no. 2 (15), s. 10.

W obszarze liberalizacji swobody przepływu osób, sygnatariusze EAWG postawili sobie za cel rozwiązanie problemów związanych z migracjami za-

\footnotetext{
${ }^{2}$ Ibidem, s. 3.
} 
robkowymi (wykres 1.). Do Federacji Rosyjskiej przyjeżdża, w poszukiwaniu pracy, corocznie (według różnych statystyk) nawet dwa miliony obywateli z byłych republik radzieckich ( $\mathrm{z}$ wyłączeniem Białorusi) ${ }^{3}$. W skrajnych przypadkach, jak Kirgistan, czy Tadżykistan, pieniądze zarobione przez migrantów za granicą stanowią, według różnych szacunków, blisko połowę dochodów tamtejszego społeczeństwa. $Z$ tego też względu, biedniejszym państwom zależy na zapewnieniu swobody dostępu do rosyjskiego rynku pracy. W ramach organizacji funkcjonuje bezwizowy ruch ludności. Gros prac ma polegać na zapewnieniu opieki społecznej migrantom, stworzeniu efektywnego systemu regulacji podatkowych i kontroli migracji. Moskwa musi też zmierzyć się z problemem asymilacji poszczególnych grup przybyszów, a często również przestępczością występującą w tych środowiskach, oraz zabezpieczyć południową granicę przed przemytem narkotyków.

\section{ZAŁOŻENIA TEORETYCZNE}

W teorii integracji ekonomicznej i w praktyce tworzenia ugrupowań integracyjnych można wyróżnić dwa etapy: pierwszy charakteryzujący się liberalizacją przepływu towarów i drugi liberalizacją przepływu usług i czynników produkcji (m.in. pracy) ${ }^{4}$. Państwa, które decydują się na utworzenie ugrupowania integracyjnego (poczynając od strefy wolnego handlu) są zazwyczaj dla siebie już przed jego utworzeniem najważniejszymi partnerami gospodarczymi i liczą, że w wyniku redukcji kosztów związanych z liberalizacją przepływów handlowych, a w dłuższej perspektywie również czynników produkcji będą osiągać wymierne korzyści. W przypadku państw, które powołały do życia EAWG mamy do czynienia $z$ sytuacją unikatową bowiem funkcjonowały one w ramach ZSRR jako elementy wspólnego organizmu gospodarczego, a następnie w latach dziewięćdziesiątych XX wieku w ich relacjach ekonomicznych nastąpił proces dezintegracji i dywersyfikacji kierunków handlowych. Obecnie państwa EAWG zajmują różne pozycje we wzajemnych obrotach handlowych i generalnie relacjach gospodarczych. Ponadto charakteryzują je ogromne dysproporcje ekonomiczne (tabela 1.).

${ }^{3}$ В. А. Ионцев, И. В. Ивахнюк, А. Г. Магомедова, И. А. Алешковский, Ю. А. Прохорова, К. Д. Шевченко, Е. В. Глод, Единый рынок труда в ЕЭП: экономический эффект согла-шений в области трудовой мигращии, „Евразийская Экономическая Интеграция. Научно-аналитический Журнал”, 2012, nо. 2 (15), s. 8.

${ }^{4}$ F. Machlup, Integracja narodziny i rozwoój idei, PWN, Warszawa 1986; P. Bożyk, J. Misala, Integracja ekonomiczna, PWE, Warszawa 2003; B. Balassa, The Theory of Economic Integration, Allen and Unwin, London 1973. 
Tabela 1. Podstawowe wskaźniki ekonomiczne państw EAWG w 2010 roku

\begin{tabular}{|c|c|c|c|c|}
\hline Państwo & $\begin{array}{c}\text { PowIERZCHNIA } \\
\left(\text { W TYSIACACH KM }{ }^{2}\right.\end{array}$ & $\begin{array}{c}\text { LUDNOŚĆ } \\
\text { (W MLN) }\end{array}$ & $\begin{array}{c}\text { PKB W 2010 R. } \\
\text { (W MLD USD) }\end{array}$ & $\begin{array}{c}\text { PKB PER CAPITA } \\
\text { W 2010 R. (USD) }\end{array}$ \\
\hline Federacja Rosyjska & $17.098,2$ & 142,9 & $1.479,8$ & $10.355,7$ \\
\hline Republika Kazachstanu & $2.724,9$ & 16,4 & 148,1 & $9.008,7$ \\
\hline Republika Białorusi & 207,6 & 9,5 & 54,7 & $5.770,8$ \\
\hline Republika Kirgiska & 199,9 & 5,5 & 4,6 & 842,6 \\
\hline Republika Tadżykistanu & 142,6 & 7,7 & 5,6 & 733,9 \\
\hline
\end{tabular}

Źródło: International Monetary Fund, World Economic Outlook Database, September 2011.

Ponieważ mimo bogatej wspólnej przeszłości mamy tu do czynienia z początkowymi etapami integracji niezmiernie ważne jest znalezienie obszarów, które ów proces mogą napędzać. W ramach teorii neofunkcjonalnej nazwano je obszarami „zazębiania się” (l'engrenage) bo przede wszystkim w ich przypadku nastąpią efekty integracyjne ${ }^{5}$. W ramach państw tworzących EAWG możemy wskazać szereg takich obszarów np. sektor energetyczny czy politykę migracyjną. Dają one wymierne podstawy aby napędzać dalsze kroki integracyjne za pomocą efektów spill-over czyli rozlewania się procesów integracyjnych, ich przenoszenia się $z$ jednego sektora na drugi ${ }^{6}$.

\section{CHARAKTERYSTYKA RYNKU PRACY PAŃSTW EAWG}

Rozpad ZSRR doprowadził do tego, że strumienie przepływu migracji wewnętrznych, między byłymi republikami radzieckimi, zyskały status międzynarodowych. Wymagało to nowego podejścia do regulowania procesów migracyjnych. W ciągu ostatnich 20 lat na przestrzeni postsowieckiej wykształcił się cały system migracyjny, w ramach którego wyraźnie wyodrębnione są bardzo atrakcyjne centra przyciągania zasobów ludzkich w Rosji i Kazachstanie. Oba te kraje są najbardziej atrakcyjne i przyciągają imigrantów, i zagranicznych pracowników $\mathrm{z}$ innych państw powstałych $\mathrm{w}$ wyniku rozpadu ZSRR choć Federacja Rosyjska odgrywa tu nieporównywalnie ważniejszą rolę. Przepisy rosyjskie dotyczące migrantów, tak jak i ich zmiany, stanowią ważny element kształtowania relacji międzynarodowych, a na obszarze

${ }^{5}$ P. C. Schmitter, Ernst B. Haas and the legacy of neofunctionalism, „Journal of European Public Policy", 12:2, April 2005,s. 255-272.

${ }^{6}$ Spill-over - rozlewanie się/pozytywna dynamika integracyjna/ekspansywna logika integracji przenoszona $\mathrm{z}$ jednego sektora na inny(zdynamizowanie jednego sektora warunkuje dynamikę kolejnego oraz ekspansję współpracy przy jej jednoczesnej instytucjonalizacji. 
EAWG kształtują nie tylko sytuację społeczno-ekonomiczną w Rosji ale również w wielu innych państwach.

Należy zauważyć, że kierunek i liczebność strumieni imigrantów na obszarze EAWG są spowodowane nie tylko czynnikami ekonomicznymi, ale również demograficznymi. $Z$ jednej strony, w Rosji i na Białorusi ma miejsce pogłębianie się kryzysu demograficznego, który przejawia się w spadku populacji, zwłaszcza $\mathrm{w}$ części społeczeństwa $\mathrm{w}$ wieku produkcyjnym, a więc mają także miejsce negatywne zmiany jakościowe w zakresie zasobów ludzkich. Z drugiej strony, Kirgizja i Tadżykistan to państwa o stosunkowo dużym i szybkim przyroście ludności, i z młodą strukturą wiekową. Kazachstan, zajmuje pośrednią pozycję między tymi dwiema grupami państw. Sytuacja demograficzna w Kazachstanie pogorszyła się bardzo w latach 90. (populacja z 17 mln w 1992 r., zmniejszyła się do 15 mln w 1999 r.). Główną rolę w zmniejszeniu populacji ludności Kazachstanu grał odpływ migrantów, który od 1992 do 2003 r. wyniósł 2,1 mln osób ${ }^{7}$.

Z kolei w Kirgistanie i Tadżykistanie zaobserwować można ekonomiczną stagnację oraz znaczny odsetek społeczeństwa żyjący w biedzie (tabela 2., PKB per capita), co prowadzi do odpływu ludności w wieku produkcyjnym. Pośrednią pozycję zajmuje Białoruś, która występuje jednocześnie jako dostawca siły roboczej (głównie do Rosji i Kazachstanu) jak również jako jej odbiorca.

$\mathrm{Z}$ powyższych powodów, a także ze względu na dysproporcje w wielkości, posiadanych zasobów i poziomie rozwoju ekonomicznego wynika, że poszczególne państwa EAWG, posiadają różne cechy swoich rynków pracy. Niemniej mamy tu do czynienia z pewną komplementarnością w tym zakresie, która jednak wymaga odpowiednich regulacji. Rosja i Kazachstan wykazują silna potrzebę dodatkowej siły roboczej, zwłaszcza wykwalifikowanej. Jednocześnie na rynkach pracy w Kirgistanie i Tadżykistanie kształtuje się wyjątkowa sytuacja, spowodowana nadmiarem siły roboczej w całym kraju ale też pojawiły się wyraźne symptomy rozpoczynającego się niedoboru siły roboczej na obszarach wiejskich ${ }^{8}$. Zagrożeniem dla wszystkich państw EAWG jest fakt, że niekontrolowana migracja pomiędzy analizowanymi krajami prowadzi do powstawania i rozwoju nieformalnego i czarnego rynku pracy oraz sprzyja korupcji (np. w Federacji Rosyjskiej), przestępczości zorganizowanej (np. w Tadżykistanie).

${ }^{7}$ В. А. Ионцев, И. В. Ивахнюк, А. Г. Магомедова, И. А. Алешковский, Ю. А. Прохорова, К. Д. Шевченко, Е. В. Глод, ор. cit., s. 8.

${ }^{8}$ Ibidem, s. 11. 


\section{KONSEKWENCJE MIGRACJI I POLITYKI MIGRACYJNEJ W EAWG}

Federacja Rosyjska, Białoruś i Kazachstan tworząc najpierw Unię celną, a następnie Wspólną Przestrzeń Gospodarczą doprowadziły jednocześnie do podpisania i wejścia w życie umowy o statusie prawnym pracowników-migrantów i członków ich rodzin oraz umowy w sprawie współpracy polegającej na przeciwdziałaniu nielegalnej migracji z państw trzecich. Oznaczało to przejście na inny jakościowo poziom wzajemnych stosunków międzypaństwowych, charakteryzujący się swobodnym i bezproblemowym przemieszczaniem pracowników na terytorium WPG. Stało się to możliwe dzięki stworzeniu nowego dla państw poradzieckich systemu, w których status prawny pracujących migrantów z państw członkowskich Wspólnoty pozwala obywatelom Rosji, Kazachstanu i Białorusi realizować swoje prawo do pracy w każdym z trzech państw, bez jakichkolwiek ograniczeń i warunków, które z reguły, obowiązują zagranicznych pracowników. W taki sposób obywatele przedstawionych państw, posiadają prawo do pracy, które jest obecnie w pełni regulowane tylko przez prawo pracy i nie klasyfikuje pracowników ze względu na obywatelstwo?.

Tabela 2. Transfery finansowe z Rosji, w formie przekazów pieniężnych (w mln USD)

\begin{tabular}{|c|c|c|}
\hline KRAJ & 2009 & 2010 \\
\hline Białoruśs & 96,1 & 164,7 \\
\hline Kazachstan & 517,2 & 565,5 \\
\hline Kirgizja & 894,3 & 1106,4 \\
\hline Tadżyistan & 1724,5 & 2215,7 \\
\hline
\end{tabular}

Źródło: В. А. Ионцев, И. В. Ивахнюк, А. Г. Магомедова, И. А. Алешковский, Ю. А. Прохорова, К. Д. Шевченко, Е. В. Глод, Единый рынок труда в ЕЭП: экономический эффект соглашений в области трудовой миграции, „Евразийская Экономическая Интеграция. Научноаналитический Журнал”, 2012, no. 2(15), s. 14 [za:] Bank Centralny Rosyjskiej Federacji.

Usunięcie granic w Unii Celnej i we Wspólnej Przestrzeni Gospodarczej między Rosją, Kazachstanem i Białorusią postawiło pytanie o włączenie do WPG Kirgistanu i Tadżykistanu. Zgodnie z założeniami EAWG należy wykonać ten krok może bez zbytniego pośpiechu ale również nie można tego działania odkładać. Po pierwsze, przyczyni się do legalizacji przepływów migracyjnych między krajami, a po drugie, wpłynie na przeniesienie granic

\footnotetext{
${ }^{9}$ Ibidem, s. 6.
} 
i kontroli celnej na zewnętrzne granice poszerzonego WPG, pomoże utworzyć bardziej namacalną barierę dla międzynarodowego handlu narkotykami, dla którego Tadżykistan jest głównym punktem przeładunkowym ${ }^{10}$.

Konsekwencje ułatwień oraz instytucjonalizacji procesów migracyjnych wewnątrz EAWG są i będą wielorakie, zależne od państwa i od perspektywy z jakiej dokonamy analizy. Dodatkowym czynnikiem umożliwiającym wymierne rezultaty w zakresie polityki migracyjnej jest zatwierdzona 13 czerwca 2012 r. Koncepcja państwowej polityki migracyjnej Federacji Rosyjskiej do 2025 r. Koncepcja została opracowana przez Federalną Służbę Migracyjną. Rosja cierpi na niedobór siły roboczej wynikający między innymi z ujemnego przyrostu naturalnego i odpływu wykształconej siły roboczej, z drugiej strony brakuje również pracowników, którzy wykonują najbardziej podstawowe prace nieatrakcyjne dla Rosjan. W związku z tym dokument jest odpowiedzią na realne zapotrzebowanie rosyjskiej gospodarki i rynku pracy. Według prognoz ekspertów z Rosyjskiej Akademii Nauk, w ciągu najbliższych pięciu lat liczba ludności aktywnej zawodowo w Rosji będzie się zmniejszać o około 1 mln rocznie - dopływ ludności z zewnątrz jest więc niezbędny inaczej bowiem Rosja nie będzie w stanie przezwyciężyć negatywnych trendów ${ }^{11}$.

Tabela 3. Szacunkowa liczba migrantów pracujących w Rosji, na podstawie danych o ich przekazach pieniężnych

\begin{tabular}{|c|c|c|c|c|}
\hline KRAJ & $\begin{array}{c}\text { PRZEKAZY PIENIĘŻNE } \\
\text { UZYSKANE PRZEZ KRAJ } \\
(2010 \text { R, MLN USD) }\end{array}$ & $\begin{array}{c}\text { MIGRANCI } \\
\text { PRACUJACY W ROSJI } \\
\text { (2010) SZACUNEK }\end{array}$ & $\begin{array}{c}\text { MIGRANCI PRACUJACYY } \\
\text { OFIJALLIIE W ROSJI } \\
(2010)\end{array}$ & $\begin{array}{c}\text { MIGRANCI } \\
\text { PRACUJACY NIELEGALNIE } \\
\text { W ROSJ (2010) }\end{array}$ \\
\hline Tadżykistan & 2032 & 425105 & 268632 & 156473 \\
\hline Kirgizja & 1160 & 242678 & 117656 & 125022 \\
\hline Kazachstan & 132 & 27615 & 8267 & 19343 \\
\hline Białoruś & 375 & 78451 & 67290 & 11162 \\
\hline
\end{tabular}

Źródło: В. А. Ионцев, И. В. Ивахнюк, А. Г. Магомедова, И. А. Алешковский, Ю. А. Прохорова, К. Д. Шевченко, Е. В. Глод, Единый рынок труда в ЕЭП: экономический эффект соглашений в области трудовой миграции, „Евразийская Экономическая Интеграция. Научноаналитический Журнал”, 2012, no. 2 (15), s. 15 [za] opracowano w na podstawie o strony: www.gks. $\mathrm{ru}$, www. cir.ru, www.belstat.gov.by, www.stat.kz, www.stat.kg, www.stat.tj.

10 В. А. Густов, Взаимовыгодное экономическое сотрудничество как основополагающий фактор развития интеграиионных проиессов на евразийском пространстве, „Евразийская Экономическая Интеграция. Научно-аналитический Журнал”, 2012, no. 2 (15), s. 37.

${ }^{11}$ K. Jarzyńska, Nowa koncepcja polityki migracyjnej Rosji, „Tydzień na Wschodzie”, 2012, no. 22 (223). 
Tabela 4. Szacunkowa liczba migrantów pracujących w Rosji, na podstawie danych o ich przekazach pieniężnych

\begin{tabular}{|c|c|c|c|c|}
\hline KRAJ & $\begin{array}{c}\text { PRZEKAZY PIENIĘŻNE } \\
\text { UZYSKANE PRZEZ KRAJ } \\
\text { (2010, MLN USD) }\end{array}$ & $\begin{array}{c}\text { MIGRANCI PRACUJACY } \\
\text { W ROSJI (2010) } \\
\text { SZACUNEK }\end{array}$ & $\begin{array}{c}\text { MIGRANCI PRACUJACY } \\
\text { OFIJALIIE W ROSJI } \\
(2010)\end{array}$ & $\begin{array}{c}\text { MIGRANCI PRACUJACY } \\
\text { NIELEGALNIE W ROSJI } \\
(2010)\end{array}$ \\
\hline Tadżykistan & 2032 & 926162 & 268632 & 657530 \\
\hline Kirgizja & 1160 & 528714 & 117656 & 411058 \\
\hline Kazachstan & 132 & 60164 & 8267 & 51897 \\
\hline Białorú́ & 375 & 170920 & 67290 & 103630 \\
\hline
\end{tabular}

Źródło: jak tab. 3.

Analizując konsekwencje przepływów siły roboczej oraz związanych z nimi dochodami i stratami gospodarczymi poszczególnych krajów szczególną uwagę należy poświęcić środkom pieniężnym migrantów, wywożonym i przesyłanym różnymi kanałami. Biorąc pod uwagę dane i obliczenia prezentowane w tabelach 2., 3., 4. można pokusić się o kilka wniosków. Po pierwsze wynagrodzenia uzyskiwane przez pracowników pochodzących z Tadżykistanu i Kirgizji, a następnie przekazywane rodzinom pozostającym w krajach pochodzenia stanowią nie tylko ważny element budżetów domowych ale również ważny element finansów całego państwa. W przypadku Tadżykistanu przepływy finansowe z Rosji stanowiły w 2010 r. połowę PKB tego kraju (tabele 1., 2., 3., 4.) w przypadku Kirgizji była to jedna czwarta PKB (tabele 1., 2., 3., 4.). Ponadto biorąc pod uwagę dane $z$ tabeli 2 . i wykresu 1. mamy tu do czynienia $z$ tendencją rosnącą. W tabelach 3. i 4. dokonano próby obliczeń nielegalnie pracujących obcokrajowców w opierając się na o transferach walutowych i danych statystycznych dotyczących osób legalnie zatrudnionych ${ }^{12}$. $\mathrm{Na}$ uwagę zasługuje fakt, że liczba osób pracujących nielegalnie może znacznie przewyższać liczbę zatrudnionych legalnie obcokrajowców i dotyczy to obywateli przybywających ze wszystkich państw Euroazjatyckiej Wspólnoty Gospodarczej. Dlatego w celu skutecznej i efektywnej współpracy w zakresie zagadnień dotyczących migracji niezbędne jest nie tylko funkcjonowanie organów koordynujących, ale również potrzebna jest skoordynowana praca parlamentów narodowych i władzy wykonawczej. Mamy tu zatem do czynienia z instytucjonalnym efektem spill-over.

12 В. А. Ионцев, И. В. Ивахнюк, А. Г. Магомедова, И. А. Алешковский, Ю. А. Прохорова, К. Д. Шевченко, Е .В. Глод, ор. cit., s. 14-15. 


\section{ZAKOŃCZENIE}

Procesy integracyjne na obszarze poradzieckim ulegają ciągłym zmianom i przekształceniom. Można zaryzykować stwierdzenie, że tak jak państwa powstałe w wyniku rozpadu ZSRR musiały na nowo określić swoją rolę, miejsce i priorytety $\mathrm{w}$ relacjach międzynarodowych, tak model procesów integracyjnych zachodzących na tym obszarze jest ciągle zmieniany w poszukiwaniu formy najbardziej optymalnej z punktu widzenia poszczególnych państw i ich uwarunkowań politycznych, ekonomicznych, geograficznych, strukturalnych, historycznych, etnicznych, kulturowych itd. W tym kontekście występuje pogląd o ważnej roli obszarów funkcjonalnych w całym procesie integracji regionalnej na obszarze poradzieckim. Według części badaczy obserwujemy obecnie proces reorientacji procesów integracyjnych $\mathrm{z}$ areny politycznej $\mathrm{w}$ kierunku współpracy sektorowej. Taki model zapobiega tworzeniu podobieństw nawiązujących do Związku Radzieckiego. Jeśli bowiem dane państwo będzie zainteresowane, może włączyć się do realizacji jednego, dwóch, trzech z pięciu zaproponowanych obszarów funkcjonalnych lub we wszystkie od razu. Jeśli pozostałe obszary okażą się nieinteresujące, można będzie w nich nie uczestniczyć ${ }^{13}$.

Integracja sektorowa bazująca na obszarach funkcjonalnych napędza proces integracyjny i powoduje efekty również w obszarach, których pozornie nie dotyczy. Prezentowana tu płaszczyzna polityki migracyjnej dotyczy żywotnych interesów społeczno-gospodarczych państw Euroazjatyckiej Wspólnoty Gospodarczej. Rynki pracy państw EAWG wykazują znaczny stopień komplementarności i w związku z tym odpowiednie wykorzystanie tego faktu daje realne podstawy do osiągania wymiernych efektów integracyjnych, a już z całą pewnością jest to ważna kwestia wymagająca wspólnych regulacji i uzgodnień. Obszarami powiązanymi są tu inwestycje, handel oraz działalność wybranych instytucji. Wpływ rosyjskiej polityki migracyjnej na przepływy inwestycji został wskazany w koncepcji rosyjskiej polityki migracyjnej do $2025 \mathrm{r}^{14} \mathrm{~W}$ przypadku Tadżykistanu i Kirgizji można zaryzykować stwierdzenie, że polityka migracyjna Federacji Rosyjskiej czy też wspólna w ramach EAWG oddziałuje na wszelkie płaszczyzny społeczno-gospodarcze tych krajów.

13 В. А. Густов, op. cit., s. 40.

${ }^{14}$ Concept of the State Migration Policy of the Russian Federation through to 2025, www.kremlin.ru, stan $\mathrm{z}$ dnia 25.06.2012. 


\section{BIBLIOGRAFIA}

Agreement On Foundation Of Eurasian Economic Community (EAEC), Astana, 10.10.2000.

Balassa B., The Theory of Economic Integration, Allen and Unwin, London 1973.

Bożyk P., Misala J., Integracja ekonomiczna, PWE, Warszawa 2003.

Concept of the State Migration Policy of the Russian Federation through to 2025, www. kremlin.ru, stan z dnia 25.06.2012.

EurAsEC Today, Eurasian Economic Community Integration Committee Secretariat, Moscow 2011.

Euroazjatyckie Wspólnoty Gospodarcze, http://evrazes.com/, stan z 05.12.2011.

Густов В. А., Взаимовыгодное экономическое сотрудничество как основополагаюший фактор развития интеграционных процессов на евразийском пространстве, „Евразийская Экономическая Интеграция. Научноаналитический Журнал”, 2012, по. 2(15).

Ионцев В. А., Ивахнюк И. В, Магомедова А. Г., Алешковский И. А., Прохорова Ю. А., Шевченко К. Д., Глод Е. В., Единый рынок труда в ЕЭП: экономический эффект согла-шений в области трудовой миграции, „Евразийская Экономическая Интеграция. Научно-аналитический Журнал”, 2012, no. 2 (15).

Jarzyńska K., Nowa koncepcja polityki migracyjnej Rosji, „Tydzień na Wschodzie”, 2012, no. 22 (223).

Карабешкинs Л. А., Внешнеполитические стратегии постсоветских стран u политика России, „Евразийская Экономическая Интеграция. Научноаналитический Журнал”, 2012, no. 2 (15).

Łomanowski A., Wptyw dzieci przywódców Azji Centralnej na sytuacje polityczna gospodarczq państw i regionu, „Bezpieczeństwo Narodowe”, Warszawa 2006.

Machlup F., Integracja narodziny i rozwój idei, PWN, Warszawa 1986.

Schmitter P. C., Ernst B. Haas and the legacy of neofunctionalism, "Journal of European Public Policy”, 12:2, April 2005, http://dx.doi.org/10.1080/13501760500043951. Waltz K., Theory of International Politics, McGraw-Hill Inc. 1979. 
